\title{
Production of annual winter forage sown before and after soybean harvest under different nitrogen fertilization levels
}

\author{
Francisco Migliorini(1), André Brugnara Soares ${ }^{(1)}$, Laércio Ricardo Sartor ${ }^{(2)}$, Paulo Fernando Adami(2), \\ Carlos Alberto Pattis ${ }^{(1)}$ e Patrícia Migliorini ${ }^{(3)}$
}

\begin{abstract}
(1)Universidade Tecnológica Federal do Paraná, Via do Conhecimento, Km 01, CEP 85503-390 Pato Branco, PR, Brazil. E-mail: francisco_migliorini@yahoo.com.br, soares@utfpr.edu.br, carlospattis@hotmail.com (2)Universidade Federal do Paraná, Departamento de Fitotecnia e Fitossanitarismo, Rua dos Funcionários, 1.540, CEP 80035-50 Curitiba, PR, Brazil. E-mail: laerciosartor@hotmail.com, paulof_adami@hotmail.com ${ }^{(3)}$ Universidade Federal de Santa Maria, Centro de Ciências Rurais, Avenida Roraima, 1000, Bairro Camobi, CEP 97105-900 Santa Maria, RS. E-mail: patricia_migliorini@hotmail.com
\end{abstract}

\begin{abstract}
The objective of this work was to evaluate the effect on forage yield of sowing winter forage species before and after soybean harvest, at different nitrogen application levels. The experiment was set out in a randomized block design with a strip-split plot arrangement, and three replicates. Sowing methods (18 days before soybean harvest and six days after soybean harvest) were allocated in the main plots, and the combination among forage species (Avena strigosa cv. IAPAR $61+$ Lolium multiflorum; A. strigosa cv. Comum + L. multiflorum; A. strigosa cv. Comum + L. multiflorum + Vicia villosa; A. strigosa cv. Comum $+L$. multiflorum + Raphanus sativus; and L. multiflorum) and nitrogen levels $\left(0,140,280\right.$ and $\left.420 \mathrm{~kg} \mathrm{ha}^{-1}\right)$ in the plots and subplots, respectively. Forage sowing before the soybean harvest made it possible to anticipate first grazing by 14 days, with satisfactory establishment of forage species without affecting forage production. This method permitted a longer grazing period, preventing the need for soil disking, besides allowing the use of no-tillage system. The mixture of forage species enables higher forage yield for pasture in relation to single species pastures, with response to nitrogen fertilization up to $360 \mathrm{~kg} \mathrm{ha}^{-1}$.

Index terms: crop-livestock system, disking process, feed gap, no-tillage, sowing date.

\section{Produção de forrageiras anuais de inverno semeadas antes e depois da colheita da soja com diferentes níveis de adubação nitrogenada}

Resumo - O objetivo deste trabalho foi avaliar o efeito na produção de pastagens de inverno, da semeadura antes e depois da colheita da soja, com diferentes níveis de aplicação de nitrogênio. O experimento foi instalado utilizando o delineamento experimental de blocos ao acaso, com parcelas subdivididas em faixas. Nas parcelas principais (faixas), foram alocadas as épocas de semeadura (18 dias antes e seis dias depois da colheita da soja) e, nas parcelas e subparcelas, a combinação entre níveis de nitrogênio $(0,140,280$ e $420 \mathrm{~kg} \mathrm{ha}^{-1}$ ) e misturas forrageiras (Avena strigosa cv. IAPAR $61+$ Lolium multiflorum; A. strigosa cv. Comum + L. multiflorum; A. strigosa cv. Comum + L. multiflorum + Vicia villosa; A. strigosa cv. Comum + L. multiflorum + Raphanus sativus; e L. multiflorum). A semeadura da forragem antes da colheita da soja possibilita antecipar o primeiro pastejo em 14 dias, com estabelecimento satisfatório das espécies forrageiras, sem afetar a produção de forragem. Este método permitiu um período de pastejo maior, evitou a necessidade de gradagem do solo, e possibilitou o uso do sistema de plantio direto. A mistura de espécies forrageiras torna possível uma produtividade maior, em comparação ao cultivo individual de espécies, com resposta à adubação nitrogenada até a dose de $360 \mathrm{~kg} \mathrm{ha}^{-1}$.

Termos para indexação: integração lavoura-pecuária, gradagem, vazio forrageiro, sistema plantio direto, data de semeadura.

\section{Introduction}

The crop-livestock system is a suitable alternative to maintain crop yield and increase animal production. One of the problems in this production system is the manner by which winter forage species are established, since most of the farmers use a disking process to set pastures, which can turn the soil susceptible to erosion. One way for solving this problem is the use of a no-tillage planter, however, most of the farmers do not have these machines. Another way is the sowing of winter forages before the soybean harvest or before the complete senescence of its leaves, that would cover the seeds and promote germination. However, no reports

Pesq. agropec. bras., Brasília, v.45, n.10, p.1209-1216, out. 2010 
were found in the literature about this procedure, especially when using mixtures of forage species.

Another important factor to be considered in subtropical regions is the forage deficit from April to the middle of July, a period known as "fall feed gap". During this period, the summer species reduce their quality and yield due to lower temperatures and shorter photoperiods. Annual winter pastures are a suitable alternative for grazing at the fall feed gap. Thus, early winter annual species sowing before the summer crop harvest in order to reduce the length this period of forage lack can be an interesting alternative (Palhares, 2005).

The primary and secondary yields of black oat (Avena strigosa Schreb.), annual ryegrass (Lolium multiflorum Lam.), rye (Secale cereale L.) and triticale (X. triticosecale Wittm. ex A. Camus), whether alone or in mixtures, have been shown in many research results (Roso etal., 1999;Aguinaga etal., 2006), with significant responses to topdressing nitrogen fertilization (Soares \& Restle, 2002a). However, nitrogen fertilization, besides its high cost to the farmers, also shows risks of environmental contamination (Soares \& Restle, 2002b), and efficient use of this nutrient should be studied in different production systems. An alternative to reduce costs and avoid environmental problems is the use of mixed pastures (grasses and legumes), since legumes have the ability to fix atmospheric $\mathrm{N}$ through symbiosis with specific bacteria.

In pastures, mixtures of grasses such as oats (early cycle production) and annual ryegrass (later cycle production) allow lower fluctuations in the supply of forage during the winter, thus extending the grazing period and maintaining the nutritional value of the pastures at appropriate levels for longer periods (Roso et al., 1999).

The objective of this work was to evaluate the effect on forage yield of sowing winter forage species before and after the soybean harvest, at different nitrogen application levels.

\section{Materials and Methods}

The work was carried out from April to October 2008, in the county of Renascença, Paraná, Brazil $\left(26^{\circ} 18^{\prime} \mathrm{S}\right.$ and $52^{\circ} 55^{\prime} \mathrm{W}$, at $800-\mathrm{m}$ altitude). The region's climate is subtropical humid, according to the Köppen classification (Maak, 1968), with $1.800 \mathrm{~mm}$ mean annual rainfall. The soil at the experimental site was a Clayey Oxisol. Soybean [Glycine $\max$ (L.) Merr.], cv. CD 214RR, was sown on December $12^{\text {th }}, 2007$, during the recommended period for the crop sowing in the southwest of Paraná state, and harvested on April $25^{\text {th }}, 2008$. Average monthly temperatures and normal precipitation during the experimental period are showed in Figure 1.

A randomized block design, with three replicates in a factorial arrangement with a strip-split plot array was used. The strip was constituted by sowing methods and was considered the main plot $(72 \times 20 \mathrm{~m})$ : broadcast sowing 18 days before soybean harvest; and broadcast sowing six days after soybean harvest, just before disking. The following forage species were used: black oat (Avena strigosa cv. IAPAR 61), annual ryegrass (Lolium multiflorum), black oat (Avena strigosa cv. Comum), hairy vetch (Vicia villosa Roth), and radish (Raphanus sativus L.). The combinations of the five forage mixtures were: black oat $\left(60 \mathrm{~kg} \mathrm{ha}^{-1}\right)+$ annual ryegrass $\left(20 \mathrm{~kg} \mathrm{ha}^{-1}\right)$; black oat cv. Comum $\left(70 \mathrm{~kg} \mathrm{ha}^{-1}\right)$ + annual ryegrass $\left(20 \mathrm{~kg} \mathrm{ha}^{-1}\right)$; black oat $\mathrm{cv}$. Comum $\left(70 \mathrm{~kg} \mathrm{ha}^{-1}\right)+$ annual ryegrass $\left(20 \mathrm{~kg} \mathrm{ha}^{-1}\right)+$ hairy vetch $\left(50 \mathrm{~kg} \mathrm{ha}^{-1}\right)$; black oat cv. Comum $\left(70 \mathrm{~kg} \mathrm{ha}^{-1}\right)+$ annual ryegrass $\left(20 \mathrm{~kg} \mathrm{ha}^{-1}\right)+$ radish $\left(10 \mathrm{~kg} \mathrm{ha}^{-1}\right)$ and; annual ryegrass $\left(30 \mathrm{~kg} \mathrm{ha}^{-1}\right)$. These combinations and the four nitrogen levels $\left(0,140,280\right.$ and $\left.420 \mathrm{~kg} \mathrm{ha}^{-1}\right)$ constituted the plots $(24 \times 4 \mathrm{~m})$ and the subplots $(6 \times 4 \mathrm{~m})$ respectively.

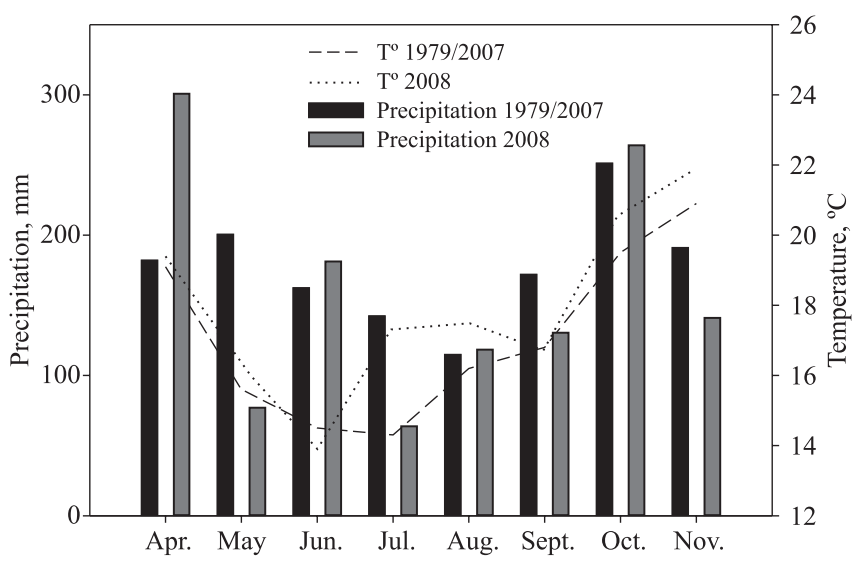

Figure 1. Average monthly temperature and total monthly precipitation during the experimental period (AprilNovember 2008), in Renascença, Paraná, Brazil. Source: Instituto Agronômico do Paraná (2009). 
Nitrogen levels were applied in topdressing with the total amount divided into two applications of equal quantities. The first application was done at the beginning of plant tillering on May $31^{\text {st }}$, or thirty days after sowing, and the second one on June $29^{\text {th }}$, using urea $(45 \% \mathrm{~N})$ as nitrogen source. Weather conditions and soil moisture were considered in the fertilization with $\mathrm{N}$ to ensure good efficiency.

Forage sowing before the soybean harvest was done on April $4^{\text {th }}, 2008$, when soybean plants had about $50 \%$ of their leaves and legumes yellowing - R7 phenological stage, according to the Fehr \& Caviness (1977) scale. Forage sowing after the soybean harvest was done on May $1^{\text {st }}, 2008$, six days after harvesting, due to rain which prevented sowing the forages earlier. Annual ryegrass showed natural reseeding owing to its growing in previous years.

The fertilization of the area was done according to the recommendations of the soil fertilization manual (Sociedade Brasileira de Ciência do Solo, 2004) for winter forage species, and according to the soil analyses $\left(\mathrm{pH}_{\mathrm{CaCl} 2}, 5.4 ; \mathrm{P}, 3.84 \mathrm{mg} \mathrm{dm}^{-3} ; \mathrm{K}, 129 \mathrm{mg} \mathrm{dm}^{-3}\right.$; $6.43 \%$ organic matter; $\mathrm{Ca}, 9.11 \mathrm{cmol}_{\mathrm{c}} \mathrm{L}^{-1} ; 75 \%$ base saturation): $130 \mathrm{~kg} \mathrm{ha}^{-1} \mathrm{P}_{2} \mathrm{O}_{5}$ and $130 \mathrm{~kg} \mathrm{ha}^{-1} \mathrm{~K}_{2} \mathrm{O}$ were used for both sowing systems applied by topdressing, on May fifth.

The forage evaluation period lasted 190 days, from the establishment of the first sowing system to the end of the experiment, on October 10, 2008, when most of the plants had flowered. Forage production was evaluated harvesting two $0.25-\mathrm{m}^{2}$ samples per plot, when the plant canopy reached on average height of $30 \mathrm{~cm}$, except for ryegrass, which was harvested at $25-\mathrm{cm}$ height. The stubble height for all treatments was seven centimeters.

For forage mass determination, subsamples were evaluated to determine the leaf:stem ratio, obtained by dividing the weight of leaf by the weight of stem dry matter. Samples were dried in a forced-air oven at $60^{\circ} \mathrm{C}$ until constant weight to determine the dry matter forage yield.

Plant height measurements (10 per plot) were done randomly using a sward stick to measure the distance from the soil to the first leaf. Evaluations were done during the pasture growing cycle, to determine the average sward height and the time of harvest. Total forage yield was determined by the sum of forage cuts, obtained along the growing cycle. After the evaluations, the pasture was standardized by cutting the whole plot to $7-\mathrm{cm}$ height. The number of seedlings for both sowing systems were evaluated on June 6 by counting the number of plants of each species in a $0.16 \mathrm{~m}^{2}$ frame, in eight samples per subplot.

The experimental results were submitted to analysis of variance (SAS Institute, 1997), using the SAS Proc GLM and the difference probability test (pdiff) at 5\% significance level. When significant, qualitative results were compared by the Tukey test, at $5 \%$ probability, and polynomial regressions for variables of quantitative effect.

\section{Results and Discussion}

There were no triple interactions (sowing system $\mathrm{x}$ pasture type $\mathrm{x}$ nitrogen level), considering all dependent variables. There was no interaction between forage mixtures $\mathrm{x}$ sowing systems on seedling density (Table 1). Seedling density of black oat (average of all mixtures which contained black oat) and radish differed between sowing systems, with higher values for sowing after the soybean harvest, which shows a greater need for bedseed for those species. However, hairy vetch and annual ryegrass showed no difference between the sowing systems, showing indifference and good acceptance of the proposed sowing method.

There was a significant interaction between sowing systems $\mathrm{x}$ forage species mixture for total forage yield (Table 2). The highest forage yield was obtained by black oat cv. Comum + ryegrass, with no difference between the sowing systems. Within sowing system, black oat cv. Comum + ryegrass mixture, with or without hairy vetch, highlights as a good option for the preharvest sowing system. In the postharvest system, black oat cv. Comum + annual ryegrass, with or without radish, is also a good option, followed by ryegrass in single cropping.

Total forage yield between sowing systems (before $\mathrm{x}$ after soybean harvest) did not differ among the mixtures: black oat cv. IAPAR 61 + ryegrass; black oat cv. Comum + ryegrass; and black oat + hairy vetch + annual ryegrass (Table 2 ), suggesting the possibility of anticipating sowing for those pastures without affecting their yield. Pasture sowing before soybean harvest is important for farmers who have no planter and use the disking process to establish annual winter forage species, since this system prevents soil

Pesq. agropec. bras., Brasília, v.45, n.10, p.1209-1216, out. 2010 
disruption and erosion. Thus, the no-tillage system maintains or increases soil organic matter, soil water holding capacity and many other benefits besides cost reduction.

As observed in Table 2, black oat cv. Comum + annual ryegrass + radish and annual ryegrass showed higher forage yield in the postharvest sowing system. Therefore, forage radish is not recommended for sowing system before the soybean harvest. It is also possible to observe a higher yield of the intercropped species in comparison to single species forage crops.

The combination black oat cv. Comum + annual ryegrass + hairy vetch sowed before the soybean harvest shows yield similar to the other forage mixtures (Table 2). Moreover, the presence of a legume in this mixture improves forage quality and also incorporates biological nitrogen to the soil. In fact, it constitutes an excellent alternative of high quality pastures as demonstrated by Fontaneli \& Freire Junior (1991), who obtained an increase of $278 \mathrm{~kg} \mathrm{ha}^{-1}$ crude protein by the use of vetch in an oat + ryegrass mixture. It can also provide good results in animal production (Grise et al., 2002).

Raphanus sativus, despite its common name in Portuguese (forage radish), has not been widely studied as a forage plant, although it can also be an alternative for mixture with pastures, based primarily on its capacity to improve soil chemical (nutrient recycling) (Derpsch \& Calegari, 1992) and physical conditions (deep and aggressive root system) (Nicoloso et al., 2008).

Black oat cv. IAPAR 61 + ryegrass mixture forage yield did not differ from the other sowing systems,

Table 1. Seedling density (plants $\mathrm{m}^{-2}$ ) of winter pastures under two sowing systems: before and after the soybean harvest ${ }^{(1)}$.

\begin{tabular}{lccc}
\hline Winter forage species & Before & After & Mean \\
\hline Black oat IAPAR 61 + ryegrass & 241 & 372 & 306 \\
Black oat cv. Comum + ryegrass & 218 & 408 & 313 \\
Black oat cv. Comum + ryegrass + hairy vetch & 214 & 407 & 310 \\
Black oat cv. Comum + ryegrass + radish & 220 & 305 & 262 \\
\hline Mean & $223 \mathrm{~b}$ & $373 \mathrm{a}$ & $1,785 \mathrm{~B}$ \\
\hline & & Ryegrass & $1,996 \mathrm{AB}$ \\
Black oat cv. IAPAR 61 + ryegrass & 2,474 & 1,096 & $1,921 \mathrm{~B}$ \\
Black oat cv. Comum + ryegrass & 2,502 & 1,407 & $1,973 \mathrm{AB}$ \\
Black oat cv. Comum + ryegrass + hairy vetch & 2,434 & 1,362 & $2,499 \mathrm{~A}$ \\
Black oat cv. Comum + ryegrass + radish & 2,584 & 1,942 & 168 \\
\hline Mean & 3,055 & Hairy vetch & 173 \\
\hline Black oat cv. Comum + ryegrass + hairy vetch & 162 & Radish & $162 \mathrm{a}$ \\
Black oat cv. Comum + ryegrass + radish & $36 \mathrm{~b}$ & 99 \\
\hline
\end{tabular}

${ }^{(1)}$ Means followed by equal letters, lowercase in the rows and capital in the columns, do not differ by the Tukey test, at $5 \%$ probability.

Table 2. Forage dry matter yield $\left(\mathrm{kg} \mathrm{ha}^{-1}\right)$ of winter forage species under two sowing systems: before and after the soybean harvest $^{(1)}$

\begin{tabular}{llcc}
\hline Winter forage species & Before & After & Mean \\
\hline Black oat cv. IAPAR 61 + ryegrass & $6,974 \mathrm{aB}$ & $7,145 \mathrm{aB}$ & 7,059 \\
Black oat cv. Comum + ryegrass & $8,808 \mathrm{aA}$ & $8,656 \mathrm{aA}$ & 8,732 \\
Black oat cv. Comum + + ryegrass + hairy vetch & $8,648 \mathrm{aAB}$ & $7,738 \mathrm{aB}$ & 8,193 \\
Black oat cv. Comum + ryegrass + radish & $7,026 \mathrm{bB}$ & $8,664 \mathrm{aA}$ & 7,855 \\
Ryegrass & $6,496 \mathrm{bB}$ & $7,824 \mathrm{aAB}$ & 7,160 \\
\hline Mean & 7,590 & 8,005 & - \\
\hline
\end{tabular}

${ }^{(1)}$ Means followed by equal letters, lowercase in the rows and capital in the columns, do not differ by the Tukey test, at $5 \%$ probability. 
except for black oat cv. Comum + ryegrass (Table 2), contradicting the results found by Macari et al. (2006). Noro et al. (2003) found dry matter of 7,230 and $5,280 \mathrm{~kg} \mathrm{ha}^{-1}$, respectively, in the comparison of black oat cv. IAPAR 61 with black oat cv. Comum.

There was no significant interaction between forage sowing methods and nitrogen levels, but there was a significant response of the pasture to nitrogen levels (Figure 2). Total forage yield adjusted to a quadratic model, with the highest yield obtained with $359 \mathrm{~kg} \mathrm{ha}^{-1}$ $\mathrm{N}$ and forage production of $9,070 \mathrm{~kg} \mathrm{ha}^{-1}$ of dry matter, showed the great need for nitrogen of this cropping system, as observed by many other authors (Restle et al., 2000; Soares \& Restle, 2002a). Lupatini et al. (1998) evaluated a black oat + ryegrass mixture with 0,150 and $300 \mathrm{~kg} \mathrm{ha}^{-1} \mathrm{~N}$ and found forage dry matter yields of 4,893, 9,327 and 10,905 $\mathrm{kg} \mathrm{ha}^{-1}$, respectively, with a linear increase as nitrogen levels were increased

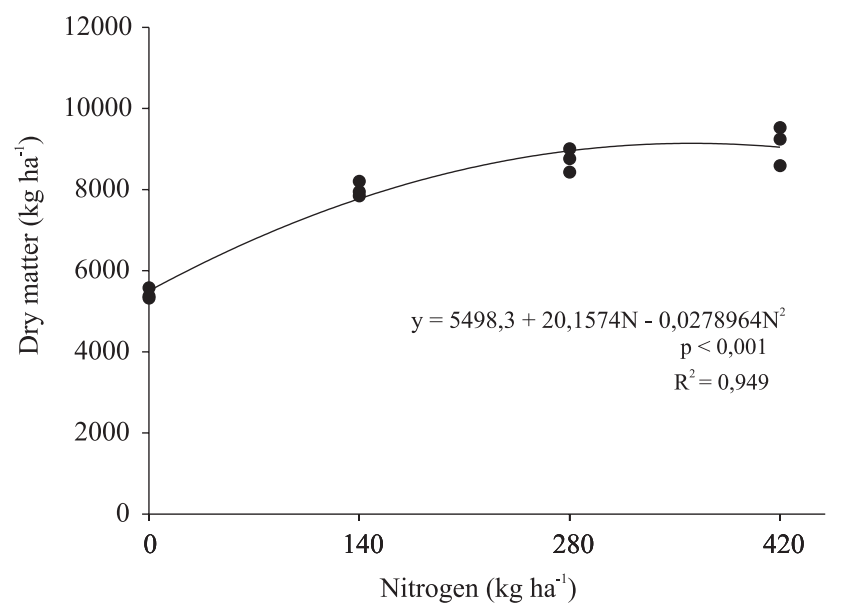

Figure 2. Total dry matter production of the winter forage species under nitrogen fertilization levels. without reaching a point of maximum efficiency of use.

Pasture sowing by broadcasting seed onto the soybean crop, without soil disking, provided a good establishment of the forage species, probably due to the soybean leaves which covered the seed at the end of its cycle. Even the mechanical harvesting of soybeans did not affect dry matter yield of most forage mixtures used. Considering these results, it is possible to prevent the disking process because there is no benefit in revolving the soil for the sowing of winter species when the preceding crop is soybean. This way, soil physical and biological properties are maintained, and anticipation of the first grazing reduces the lack of forage in the fall, decreasing the cost of animal feeding.

There was a significant interaction between sowing system and mixture of forage species (Table 3) for time (days) from soybean harvesting to first grazing or cutting. It was also noted that it is possible to anticipate the first cutting or the first grazing by sowing forage species before the soybean harvest. There was no difference between black oat + hairy vetch + ryegrass mixture and ryegrass alone in both sowing systems. For the other three forage mixtures, it was possible to anticipate the first grazing by 14 days, when they were sowed before the soybean harvest. There is a necessary period of time, between the soybean harvest and first grazing, required by the plant to ensure good pasture establishment. This period is responsible for the autumn forage deficit. Therefore, decreasing this time period by earlier forage sowing can provide forage availability in advance, reducing the cost on supplements or conserving forage. Annual ryegrass and the mixture with hairy vetch needed more time before using the pasture, probably due to the unfavorable photoperiod

Table 3. Period (days) from soybean harvest to first cut of winter forage species under different sowing systems: before and after the soybean harvest ${ }^{(1)}$.

\begin{tabular}{lccc}
\hline Winter forage species & Before & After & Mean \\
\hline Black oat cv. IAPAR 61 + ryegrass & $58 \mathrm{aA}$ & $72 \mathrm{bA}$ & 65 \\
Black oat cv. Comum + ryegrass & $58 \mathrm{aA}$ & $72 \mathrm{bA}$ & 65 \\
Black oat cv. Comum + + ryegrass + hairy vetch & $71 \mathrm{aB}$ & $72 \mathrm{aA}$ & 71 \\
Black oat cv. Comum + ryegrass + radish & $58 \mathrm{aA}$ & $72 \mathrm{bA}$ & 65 \\
Ryegrass & $71 \mathrm{aB}$ & $75 \mathrm{aA}$ & 73 \\
\hline Mean & 63 & 73 & - \\
\hline
\end{tabular}

${ }^{(1)}$ Means followed by equal letters, lowercase in the rows and capital in the columns, do not differ by the Tukey test, at $5 \%$ probability. 
and low temperature of the initial development period, which reduced forage growth. According to Floss (1989) and to Pereira et al. (2008), higher temperatures encourage ryegrass and vetch growth resulting in higher dry matter accumulation in the spring.

Annual ryegrass, when alone, takes longer before grazing, so combining it with other earlier cycle forage species such as oats or triticale is a good strategy to reduce the needed time before grazing (Noro et al., 2003). Thus, the use of mixed forage species promotes a more uniform supply of better quality forage, extending the grazing period as well (Roso et al., 1999).

Furthermore, the period of forage use, from first to last cut, is greater when sowing is anticipated. Some of the forage species sown before the soybean harvest anticipated foraging by 14 days, as was the case with black oat IAPAR $61+$ ryegrass, black oat Comum + ryegrass and black oat Comum + radish (Table 3 ), allowing a better use of the area with higher profits, as a consequence of higher animal production due to the longer time of use.

As can be seen in Table 4, there was a significant interaction between sowing system and forage mixtures for the length of time from sowing to first harvest. A longer period was observed for the plants sown before the soybean crop harvest, due to less light availability and poor bedseed, preventing adequate contact of the seeds with the soil. However, even so, this sowing system allowed the anticipation of use (Table 3) for most of the forage species, suggesting that this sowing system is more suitable.

Moreover, there was a significant interaction between sowing system and forage mixtures in the forage yield of the first cut (Table 5). Mixtures that included black oat cv. Comum, at the soybean post harvest sowing system, were the most productive at the first cut, although not differing from annual ryegrass alone. In the sowing system before soybean harvest, there was a higher dry matter yield of the first cut for black oat + ryegrass + hairy vetch and ryegrass alone.

Forage production in the first cut was linearly influenced by nitrogen levels (Figure 3), showing that larger amounts of nitrogen may influence forage production in the first cut. However, it did not influence the forage period of use or the length of time from sowing to first graze, cut or harvest.

Table 4. Period (days) from sowing to first harvest of winter forage species under different sowing systems: before and after the soybean harvest ${ }^{(1)}$.

\begin{tabular}{lccc}
\hline Winter forage species & Before & After & Mean \\
\hline Black oat cv. IAPAR 61 + ryegrass & $76 \mathrm{bB}$ & $66 \mathrm{aB}$ & 71 \\
Black oat cv. Comum + ryegrass & $76 \mathrm{bB}$ & $66 \mathrm{aB}$ & 71 \\
Black oat cv. Comum + + ryegrass + hairy vetch & $89 \mathrm{bA}$ & $66 \mathrm{aB}$ & 77 \\
Black oat cv. Comum + ryegrass + radish & $76 \mathrm{bB}$ & $66 \mathrm{aB}$ & 71 \\
Ryegrass & $89 \mathrm{bA}$ & $69 \mathrm{aA}$ & 79 \\
\hline Mean & 81 & 67 & - \\
\hline
\end{tabular}

${ }^{(1)}$ Means followed by equal letters, lowercase in the rows and capital in the columns, do not differ by the Tukey test, at $5 \%$ probability.

Table 5. Forage dry matter yield $\left(\mathrm{kg} \mathrm{ha}^{-1}\right)$ at the first cut of winter forage species under two sowing systems: before and after the soybean harvest ${ }^{(1)}$.

\begin{tabular}{lccc}
\hline Winter forage species & Before & After & Mean \\
\hline Black oat cv. IAPAR 61 + ryegrass & $842 \mathrm{aB}$ & $1,105 \mathrm{aB}$ & 974 \\
Black oat cv. Comum + ryegrass & $874 \mathrm{bB}$ & $1,781 \mathrm{aA}$ & 1,327 \\
Black oat cv. Comum + + ryegrass + hairy vetch & $1,348 \mathrm{aA}$ & $1,616 \mathrm{aA}$ & 1,482 \\
Black oat cv. Comum + ryegrass + radish & $852 \mathrm{aB}$ & $1,631 \mathrm{aA}$ & 1,241 \\
Ryegrass & $1,201.2 \mathrm{aA}$ & $1,579 \mathrm{aA}$ & 1,390 \\
\hline Mean & 1,023 & 1,542 & - \\
\hline
\end{tabular}

${ }^{(1)}$ Means followed by equal letters, lowercase in the rows and capital in the columns, do not differ by the Tukey test, at $5 \%$ probability. 


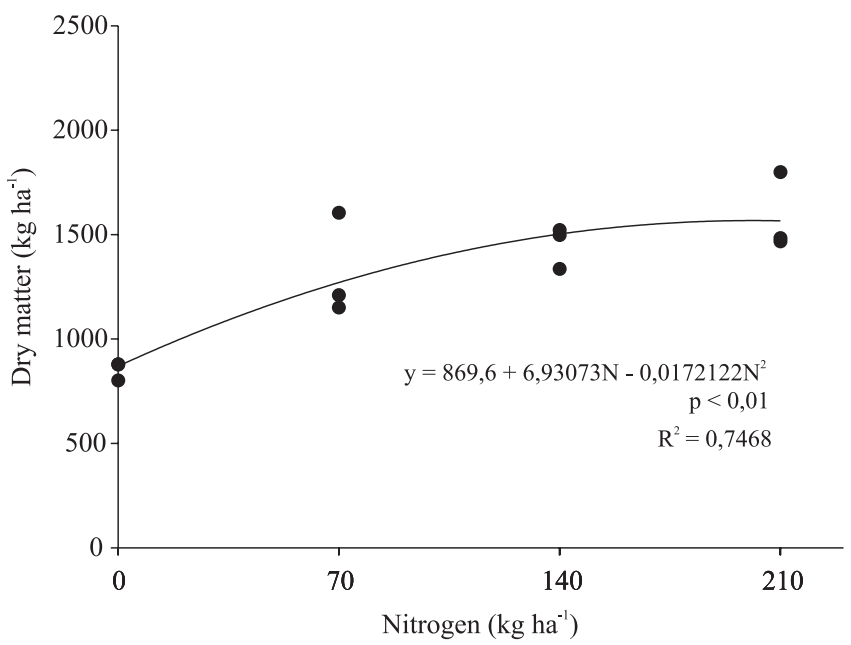

Figure 3. Dry matter production in the first cut of winter forage species under different nitrogen fertilization levels.

\section{Conclusions}

1. Pasture sowing before the soybean harvest anticipates first grazing, allowing a longer grazing period, reducing forage deficit in the autumn and making it possible to prevent disking the soil.

2. Total forage production was not affected by the sowing system.

3. Mixtures of forage species enable higher forage yields for pasture in comparison to pasture sown alone, with response to nitrogen fertilization up to $360 \mathrm{~kg} \mathrm{ha}^{-1}$.

\section{Acknowledgments}

To Conselho Nacional de Desenvolvimento Científico e Tecnológico, for scholarship support.

\section{References}

AGUINAGA, A.A.Q.; CARVALHO, P.C. de F.; ANGHINONI, I.; SANTOS, D.T. dos; FREITAS, F.K. de; LOPES, M.T. Produção de novilhos superprecoces em pastagem de aveia e azevém submetida a diferentes alturas de manejo. Revista Brasileira de Zootecnia, v.35, p.1765-1773, 2006.

DERPSCH, R.; CALEGARI, A. Plantas para adubação verde de inverno. 2.ed. Londrina: IAPAR, 1992. 78p. (IAPAR. Circular, 73).

FEHR, W.R.; CAVINESS, C.E. Stages of soybean development. Ames: Iowa State University, 1977. 11p. (Special report, 80).

FLOSS, E.L. Aveia. In: BAIER, A.C.; FLOSS, E.L.; AUDE, M.I. da S. As lavouras de inverno. Rio de Janeiro: Globo, 1988. p.76-106.
FONTANELI, R.S.; FREIRE JUNIOR, N. Avaliação de consorciações de aveia e azevém anual com leguminosas de estação fria. Pesquisa Agropecuária Brasileira, v.26, p.623-630, 1991.

GRISE, M.M.; CECATO, U.; MORAES, A.; FACCIO, P.C.C.; CANTO, M.W. do; JOBIM, C.C.; RODRIGUES, A.M. Avaliação do desempenho animal e do pasto na mistura aveia IAPAR 61 (Avena strigosa Schreb.) e ervilha forrageira (Pisum arvense L.) manejada em diferentes alturas. Revista Brasileira de Zootecnia, v.31, p.1085-1091, 2002.

INSTITUTO AGRONÔMICO DO PARANÁ. Médias históricas em estações do IAPAR: Pato Branco e Francisco Beltrão. Disponível em: <http:/www.iapar.br/modules/conteudo/conteudo. php? conteudo $=668>$. Acesso em: 8 jul. 2009.

LUPATINI, G.C.; RESTLE, J.; CERETTA, M.; MOOJEN, E.L.; BARTZ, H.R. Avaliação da mistura de aveia-preta e azevém sob pastejo submetida a níveis de nitrogênio. Pesquisa Agropecuária Brasileira, v.23, p.1939-1943, 1998.

MACARI, S.; ROCHA, M.G. da; RESTLE, J.; PILAU, A.; FREITAS, F.K.; NEVES, F.P. Avaliação da mistura de cultivares de aveia-preta (Avena strigosa Schreb.) com azevém (Lolium multiflorum Lam.) sob pastejo. Ciência Rural, v.36, p.910-915, 2006.

NICOLOSO, R. da S.; AMADO, T.J.C.; SCHNEIDER, S.; LANZANOVA, M.E.; VITOR, C.G.; BRAGAGNOLO, J. Eficiência da escarificação mecânica e biológica na melhoria dos atributos físicos de um Latossolo muito argiloso e no incremento do rendimento da soja. Revista Brasileira de Ciência do Solo, v.32, p.1723-1734, 2008.

NORO, G.; SCHEFFER-BASSO, S.M.; FONTANELLI, P.S.; ANDREATTA, E. Gramíneas anuais de inverno para produção de forragem: avaliação preliminar de cultivares. Agrociência, v.7, p.35-40, 2003.

PALHARES, M. Alternativas para a formação de palha. In: WORKSHOP SOBRE O SISTEMA PLANTIO DIRETO NO ESTADO DE SÃO PAUlO, 2005, Campinas. Anais. Piracicaba: Fundação Agrisus: FEALQ; Campinas: Instituto Agronômico, 2005. p.21-26.

PEREIRA, V.A.; MITTELMANN, A.; SILVA, F.J.; SOUZA, F.S.; AUAD, A.M.; OLIVEIRA, J.S. Comportamento agronômico de populações de azevém anual (Lolium multiflorum L.) para cultivo invernal na Região Sudeste. Ciência Agrotécnica, v.32, p.567-572, 2008.

RESTlE, J.; ROSO, C.; SOARES, A.B. Produtividade animal e retorno econômico em pastagem de aveia-preta mais azevém adubada com fontes de nitrogênio em cobertura. Revista Brasileira de Zootecnia, v.29, p.357-364, 2000.

ROSO, C.; RESTLE, J.; SOARES, A.B.; ALVES FILHO, D.C.; BRONDANI, I.L. Produção e qualidade de forragem da mistura de gramíneas anuais de estação fria sob pastejo contínuo. Revista Brasileira de Zootecnia, v.28, p.459-467, 1999.

SAS INSTITUTE. SAS'S user's guide. Cary: SAS Institute, 1997. 46p.

SOARES, A.B.; RESTLE, J. Adubação nitrogenada em pastagem de triticale mais azevém sob pastejo com lotação contínua: recuperação de nitrogênio e eficiência na produção de forragem.

Revista Brasileira de Zootecnia, v.31, p.43-51, 2002a. 
SOARES, A.B.; RESTLE, J. Produção animal e qualidade de forragem de pastagem de triticale e azevém submetida a doses de adubação nitrogenada. Revista Brasileira de Zootecnia, v.31, p.908-917, 2002b.
SOCIEDADE BRASILEIRA DE CIÊNCIA DO SOLO. Comissão de Química e Fertilidade do Solo. Manual de adubação e de calagem para os Estados do Rio Grande do Sul e de Santa Catarina. 10.ed. Porto Alegre: SBCS, 2004. 400p.

Received on June 24, 2009 and accepted on September 30, 2010 